\title{
RELATION OF FISH COMMUNITIES TO ENVIRONMENTAL CONDITIONS IN URBAN STREAMS OF THE WASATCH FRONT, UTAH
}

\author{
Elise M. Giddings ${ }^{1}$, Larry R. Brown ${ }^{2}$, Terry M. Short ${ }^{3}$, and Michael R. Meador ${ }^{4}$
}

\begin{abstract}
Twenty-eight sites along the Wasatch Front, north central Utah, representing the range of urban land use intensity for wadeable streams of the area, were sampled in September 2000. Fish communities were assessed by single-pass electrofishing, and physical habitat and water-quality characteristics were measured. On average, nonnative species comprised $54 \%$ of species richness and $53 \%$ of relative abundance, although only Salmo trutta and Pimephales promelas were very abundant at any 1 site. Salmo trutta and Catostomus platyrhynchus, a native species, were the most widely distributed and abundant species captured. Analysis of fish communities using nonmetric multidimensional scaling (NMDS) revealed a community gradient from sites dominated by Salmo trutta and Cottus species (C. bairdi, C. beldingi) to sites dominated by Catostomus platyrhynchus. Sites dominated by C. platyrhynchus were smaller in size and had less habitat cover, smaller average substrate size, higher concentrations of dissolved constituents, and higher water temperature than sites dominated by S. trutta. Sites dominated by C. platyrhynchus were located in more intensely urbanized watersheds at lower elevations. Stream size and associated instream habitat availability appear to limit S. trutta distribution and abundance, while native species appear more tolerant of decreased water quality and increased water temperatures in more urbanized streams. Most of the study sites are affected by development of water infrastructure for human water use (e.g., dams and diversions), and this infrastructure may play a role in dispersal of species.
\end{abstract}

Key words: Fish communities, brown trout, mountain sucker, urbanization, Utah, water quality.

Urbanization is a global issue that affects the quantity and quality of water resources for all biota, including humans (Baer and Pringle 2000). Streams and rivers in urban areas have altered geomorphology, hydrology, energy flow, and water chemistry (Hammer 1972, Klein 1979, Douglas 1983, Booth and Jackson 1997, Finkenbine et al. 2000). These changes can lead to a decline in the richness and abundance of biological communities (Pedersen and Perkins 1986, Sonneman et al. 2001, Walsh et al. 2001). Fish communities in urban streams may exhibit a loss of species and lower overall fish densities (Weaver and Garman 1994, Wang et al. 2000), a change from intolerant to tolerant species (Kemp and Spotila 1997), and shifts in biomass among species and age classes (Scott et al. 1986).

In the semiarid or arid climates of the western United States, urbanization and the often concomitant increases in water demand are particularly stressful for aquatic systems. In Utah about 1.7 million people live along the western flanks of the Wasatch Range, a north-south trending mountain range in an area called the Wasatch Front (U.S. Census Bureau 2000). The
3 largest cities in Utah (Salt Lake City, Provo, and Ogden) are located along the Wasatch Front and the population within these metropolitan areas is expected to increase by $30 \%$ in the next 20 years (Campbell 1997). Utah is the 2 nd driest state in the United States, with a statewide average annual precipitation of $33 \mathrm{~cm}$, and ranks 2 nd in per capita water use (Solley et al. 1998). Forty-five percent of public-supply water along the Wasatch Front consists of surface water supplied by a series of reservoirs and diversions (U.S. Geological Survey 1995). Rapid population growth will likely cause increased demands on the water supply system. And increased water storage and diversion are likely to cause substantial water-quality and habitat change leading to severe effects on the resident biota. Minimizing these negative effects requires that managers understand the processes causing them. The goal of this study was to examine fish community structure in streams of the urban environment of the metropolitan Wasatch Front, Utah, in relation to environmental conditions and several measures of urbanization. In particular we were interested

\footnotetext{
${ }^{1}$ U.S. Geological Survey, 3916 Sunset Ridge Road, Raleigh, NC 27607.

${ }^{2}$ U.S. Geological Survev, Placer Hall, 6000 J Street, Sacramento, CA 95819-6129.

${ }^{3}$ U.S. Geological Survey, 345 Middlefield Road, Menlo Park, CA 94025.

${ }^{4}$ U.S. Geological Survey, 12201 Sunrise Valley Drive, MS 413, Reston, VA 20192.
} 
in determining the environmental or urban factors most strongly correlated with the distribution of fish species.

\section{Study Area}

The study area is in north central Utah and includes all drainage basins that drain into the Great Salt Lake from the east (Fig. 1). Urban development is most extensive in the alluvial valleys and along the narrow benches of the Wasatch Front. Steep topography and extensive publicly owned lands have limited development at higher elevations. Streams selected for this study are located within or just upstream of the major metropolitan areas, primarily in Salt Lake City, Ogden, and Provo (Fig. 1). All selected streams have their headwaters in the Wasatch and Uinta Mountain ecoregion and flow through an urban area in the Central Basin and Range ecoregion (Omernik 1994) to their eventual terminus in the Great Salt Lake.

\section{METHODS}

\section{Site Selection}

Field reconnaissance identified 14 streams that met our requirements of being perennially flowing and wadeable. One stream was eliminated from consideration because, within the urban area, the channel was concrete lined. We adopted a nested design for site selection that encompassed a range of landscape urbanization and included less urbanized locations closer to the mountain front and more intensively urbanized areas farther from the mountain front. The design allowed from 1 to 3 sites, roughly corresponding to the length of the stream flowing through the urban area, on each of the 13 available streams (i.e., streams with longer urban reaches had 3 sites, while streams with shorter urban reaches had 1 site). A maximum of 3 sites per stream limited the proximity of sites on the same stream while maximizing the range of urbanization sampled. A total of 28 sites were selected for accessibility, sampling feasibility, and distribution across the range of urban conditions as defined by an index of urbanization described below (Table 1). Total drainage basin areas ranged from $9 \mathrm{~km}^{2}$ to $1764 \mathrm{~km}^{2}$. Drainage basins were delineated from a $30-\mathrm{m}$ digital elevation model in conjunction with geographic information system (GIS) programs (U.S. Geological Survey 2000).
The headwater reaches of the drainage basins were primarily forested. Because of the relatively local distribution of urban development, only land cover in the lower parts of the basins and within the boundaries of the Central Basin and Range ecoregion was used to calculate the percentage of urban land use, the extent of urban infrastructure, and the accompanying socioeconomic characteristics used in derivation of the urban index.

We used a multimetric index of land-use intensity to characterize the degree of urbanization in each drainage basin. The urban index was modified from an index calculated by McMahon and Cuffney (2000) and included (1) biophysical measures of the urban landscape such as land cover; (2) measures of the infrastructure that supports urban development patterns such as road density and sewer use; (3) socioeconomic measures describing factors such as population, housing, and income; and (4) measures of lithology and soil-drainage characteristics. We used land-use data developed by the Multi-Resolution Land Characteristics (MRLC) consortium and based on Landsat Thematic Mapper satellite images from the early 1990s (Loveland and Shaw 1996). At the time of site selection, these were the most recent land cover data available that included all of the study sites. Other data sources are the same as those utilized by McMahon and Cuffney (2000).

To develop the index, 75 variables of landuse, urban infrastructure, socioeconomic characteristics, and environmental setting were correlated with 1999 population density and drainage area. Where appropriate, variables were normalized for drainage area. Variables were included in the urban index only if the absolute value of the Spearman rank correlation with 1999 population density was $\geq 0.50$ and the absolute value of the correlation with drainage area was $<0.50$. This resulted in 13 variables used to calculate the urban index: (1) percentage of riparian area $(250-\mathrm{m}$ buffer each side) in urban land; (2) percentage of riparian area with tree coverage; (3) percentage of riparian area with shrub coverage; (4) percentage of watershed area in urban land; (5) percentage of watershed area with tree coverage; (6) percentage of watershed area with shrub coverage; (7) road density in watershed; (8) percentage of houses in watershed on sewer; (9) change in 

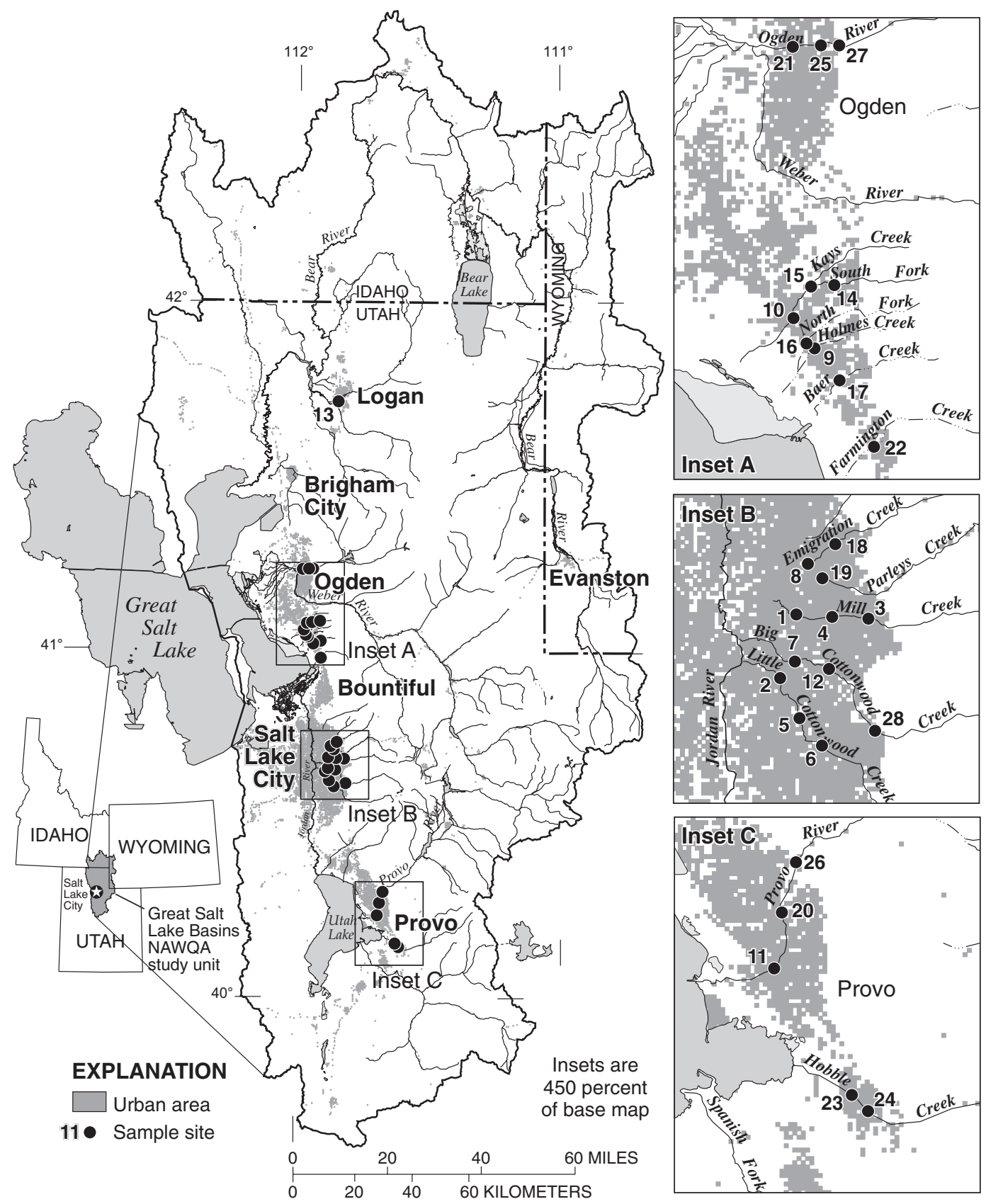

Fig. 1. Location of study sites. Map codes and site names are presented in Table 1.

population density from 1990 to 1999; (10) socioeconomic index 2 ; (11) percentage of watershed area with well-drained soils; (12) percentage of watershed area with moderately drained soils; and (13) percentage of watershed lithology as lake sediment and playa. Socio- economic index 2 increased with the density of housing units, number of households, percentage of rental units, and population; it was developed using an ordination of population, labor, income, and housing census variables (McMahon and Cuffney 2000). Each of the 13 
TABLE 1. Names, map codes, site codes, water-supply infrastructure, urban index values, fish species richness, and drainage area of sites sampled along the Wasatch Front in 2000. Map codes refer to Fig. 1.

\begin{tabular}{|c|c|c|c|c|c|c|}
\hline Site name & $\begin{array}{l}\text { Map } \\
\text { code }\end{array}$ & $\begin{array}{l}\text { Site } \\
\text { code }\end{array}$ & $\begin{array}{c}\text { Water } \\
\text { infra- } \\
\text { structure }\end{array}$ & $\begin{array}{l}\text { Urban } \\
\text { index }\end{array}$ & $\begin{array}{c}\text { Fish } \\
\text { species } \\
\text { richness }\end{array}$ & $\begin{array}{c}\text { Drainage } \\
\text { area } \\
\left(\mathrm{km}^{2}\right)\end{array}$ \\
\hline $\begin{array}{l}\text { Mill Creek, } 300 \text { East Street, } \\
\text { Salt Lake City }\end{array}$ & 1 & M300 & CA2 & 100 & 5 & 84.7 \\
\hline $\begin{array}{l}\text { Little Cottonwood Creek, Murray Park, } \\
\text { Salt Lake City }\end{array}$ & 2 & LCMU & LW, CA2 & 90 & 4 & 112.9 \\
\hline $\begin{array}{l}\text { Mill Creek, } 3060 \text { East Street, } \\
\text { Salt Lake City }\end{array}$ & 3 & M3060 & None & 88 & 2 & 59.6 \\
\hline $\begin{array}{l}\text { Mill Creek, } 2000 \text { East Street, } \\
\text { Salt Lake City }\end{array}$ & 4 & M2000 & CA2 & 87 & 1 & 60.1 \\
\hline $\begin{array}{l}\text { Little Cottonwood Creek, Wheeler Farm, } \\
\text { Salt Lake City }\end{array}$ & 5 & LCWH & LW, CA2 & 84 & 5 & 97.6 \\
\hline $\begin{array}{l}\text { Little Cottonwood Creek, Crestwood Park, } \\
\text { Salt Lake City }\end{array}$ & 6 & LCCRE & $\mathrm{LW}$ & 80 & 2 & 93.8 \\
\hline $\begin{array}{l}\text { Big Cottonwood Creek, } 900 \text { East Street, } \\
\text { Salt Lake City }\end{array}$ & 7 & BC900 & LW, CA2 & 78 & 7 & 184.1 \\
\hline $\begin{array}{l}\text { Emigration Creek, } 1200 \text { East Street, } \\
\text { Salt Lake City }\end{array}$ & 8 & E1200 & SI & 75 & 1 & 73.6 \\
\hline Holmes Creek, Main Street, Layton & 9 & HOLM & SI & 74 & 5 & 8.8 \\
\hline Kays Creek, Layton & 10 & KLAY & SI & 73 & 3 & 28.0 \\
\hline Provo River, 800 North Street, Provo & 11 & P800 & LI, CAl & 71 & 5 & 1764.0 \\
\hline $\begin{array}{l}\text { Big Cottonwood Creek, Cottonwood Mall, } \\
\text { Salt Lake City }\end{array}$ & 12 & BCMAL & LW, CA2 & 70 & 10 & 160.3 \\
\hline Logan River, Golf Course Road, Logan & 13 & LOG & LW, CAl & 69 & 5 & 562.3 \\
\hline South Fork Kays Creek, Layton & 14 & SFK & SI & 68 & 1 & 12.9 \\
\hline Kays Creek, 1000 East Street, Layton & 15 & K1000 & SI & 67 & 1 & 23.8 \\
\hline $\begin{array}{l}\text { North Fork Holmes Creek, Main Street, } \\
\text { Layton }\end{array}$ & 16 & NKHO & SI & 64 & 2 & 14.2 \\
\hline Baer Creek, Frontage Road, Kaysville & 17 & BAFR & LW & 61 & 2 & 12.7 \\
\hline $\begin{array}{l}\text { Emigration Creek, } 1300 \text { South Street, } \\
\text { Salt Lake City }\end{array}$ & 18 & $\mathrm{E} 1300$ & SI & 56 & 1 & 72.5 \\
\hline $\begin{array}{l}\text { Parley’s Creek, Sugarhouse Park, } \\
\text { Salt Lake City }\end{array}$ & 19 & PARL & LI, LW & 56 & 1 & 139.9 \\
\hline Provo River, 3700 North Street, Provo & 20 & P3700 & LI, CAl & 50 & 2 & 1714.1 \\
\hline $\begin{array}{l}\text { Ogden River, Washington Avenue, } \\
\text { Ogden }\end{array}$ & 21 & OWAS & LI, CAl & 47 & 8 & 858.8 \\
\hline $\begin{array}{l}\text { Farmington Creek, Frontage Road, } \\
\text { Farmington }\end{array}$ & 22 & FARM & SI & 46 & 4 & 32.6 \\
\hline Hobble Creek, Center Street, Springville & 23 & HCEN & SI, LW & 43 & 2 & 320.1 \\
\hline Hobble Creek, 800 East Street, Springville & 24 & $\mathrm{H} 800$ & SI, CA2 & 38 & 3 & 319.1 \\
\hline Ogden River, Harrison Avenue, Ogden & 25 & OHAR & LI & 35 & 6 & 857.5 \\
\hline Provo River, Highway 189, Orem & 26 & P189 & LI, CAl & 29 & 3 & 1709.9 \\
\hline Ogden River, Valley Drive, Ogden & 27 & OVAL & LI & 3.5 & 5 & 855.2 \\
\hline $\begin{array}{l}\text { Big Cottonwood Creek, above water } \\
\text { treatment plant, Salt Lake City }\end{array}$ & 28 & BCWTP & None & 0 & 2 & 128.7 \\
\hline
\end{tabular}

selected variables was standardized across the sites to produce a score that ranged from 0 to 1 . Variables that negatively correlated with population density were adjusted by subtracting the standardized score from 1 so that all scores would increase as population density increased. At each site the 13 variable scores were averaged. The average scores were then standardized to produce an urban index that ranged from 0 (minimal urbanization) to 100 (intense urbanization; Table 1 ).

Quantification of the water-supply infrastructure was not possible given the complexity of the drainage networks within the Great Salt Lake metropolitan area; accordingly, variables associated with the water-use infrastructure were not included in the derivation of the urban index. Instead, these variables were 
assessed separately as categorical measures based on the presence of large $\left(>6\right.$ million- $\left.\mathrm{m}^{3}\right)$ or small $\left(<6\right.$ million-m $\left.{ }^{3}\right)$ impoundments, occurrence of large water withdrawals $(>50 \%$ of summer baseflow), and occurrence of flow augmentations from canal water additions, including both intra- and interbasin transfers.

\section{Data Collection}

At each site biological and habitat data were collected within a sampling reach that was a minimum of 20 times the mean channel width, a length that encompassed at least 1 complete meander wavelength in natural, meandering channels (Fitzpatrick et al. 1998). Sampling reaches ranged in length from $100 \mathrm{~m}$ to $295 \mathrm{~m}$ $(\bar{x}=179 \mathrm{~m})$, and ratios of reach length to wetted channel width (channel width ratios) ranged from 20 to $100.5(\bar{x}=38.2)$. Sampling reaches were selected so that they did not include anthropogenic features such as bridges and culverts, large storm drains, or canal crossings.

Fish were collected during low flow in September 2000 using pulsed direct-current backpack electrofishing. Electrofishing began at the downstream boundary of the sampling reach, and a single pass was conducted in an upstream direction. All habitats were systematically surveyed along the entire length of the sampling reach. Patton et al. (2000) noted that western streams require less effort to sample compared to eastern streams and reported that $100 \%$ of the fish species present in Wyoming streams were collected with a single electrofishing pass for reach lengths of 50-200 m and channel width ratios of 14-50. Actual shocking time (seconds) was recorded. All captured fish were identified to species and counted. Fish that could not be identified in the field, primarily Cottus spp. and small cyprinids (Cyprinidae), were retained for later identification in the laboratory by one of the authors (LRB) using taxonomic keys provided in Sigler and Sigler (1996).

Stream habitat and geomorphology were characterized at each site by establishing 11 equidistant transects perpendicular to stream banks following procedures described by Fitzpatrick et al. (1998). Change in water surface elevation along the length of the reach was determined by surveying and used to calculate water surface gradient. At each transect, bankfull and wetted channel widths were measured, and the percentage of riparian vegetative cover was determined using a spherical densiometer (Platts et al. 1987). In addition, water depth, velocity, and bed substrate particle size were quantified at 33 locations (3 per transect), and presence or absence of instream habitat cover was noted at 55 locations (5 per transect). Habitat cover represented the numbers and types of habitat structures (overhanging vegetation, undercut banks, woody debris, boulders, and macrophyte beds) that could provide refuge for juvenile and adult fishes. Bed substrate particle size was characterized using a categorical scale of $0.1-10$, with 0.1 being the smallest particles (silt/clay) and 10 being the largest (large boulders). Average values were calculated for depth, velocity, and substrate size.

Water samples were collected at each site during July 2000 for determination of water chemistry. Water-column samples were collected by using an equal-width-increment method and field processed according to U.S. Geological Survey (USGS) protocols (Shelton 1994). Water samples were sent to the USGS National Water Quality Laboratory (NWQL) where they were analyzed for major-ion concentration, nitrogen and phosphorous species, and dissolved pesticides (Fishman et al. 1994). Pesticide data were summarized by counting the number of pesticides (herbicides and insecticides) detected at each site. During the waterchemistry sampling visit, a discharge measurement and an instantaneous measurement of dissolved oxygen were taken. Continuous temperature-monitoring probes were placed at the sites from March 2000 through March 2001. Temperature was recorded at 15-minute intervals, and annual and seasonal statistics were calculated for each site. The summer season was defined as 15 June to 15 September. The final set of 15 environmental variables included 10 physical and 5 water-quality variables (Table 2).

Seven measures of urbanization were used to assess the association of fish communities with urban conditions: (1) percentage of developed land in watershed, (2) percentage of forested land in watershed, (3) percentage of houses on public sewer, (4) road density, (5-6) two socioeconomic indices, and (7) the urban intensity index (Table 2). The socioeconomic indices were developed by McMahon and Cuffney (2000) using an ordination of census variables. The 1st socioeconomic index (SEI 1) increased with average household income, household expenditure levels, and number of 
TABLe 2. Mean and range $(n=28)$ for physical, chemical, and urban variables and Spearman's correlation (rho) between variable values and site scores for NMDS axis 1 and 2 . Rho values greater than $|0.5|$ are bolded.

\begin{tabular}{|c|c|c|c|c|}
\hline Variables & Mean & Range & $\begin{array}{l}\text { NMDS } \\
\text { Axis } 1\end{array}$ & $\begin{array}{c}\text { NMDS } \\
\text { Axis } 2\end{array}$ \\
\hline \multicolumn{5}{|l|}{ PHYSICAL VARIABLES } \\
\hline Elevation $(\mathrm{m})$ & 1361 & $1250-1539$ & -0.54 & 0.57 \\
\hline Discharge $\left(\mathrm{m}^{3} \cdot \mathrm{s}^{-1}\right)$ & 0.22 & $0.01-3.57$ & -0.56 & -0.04 \\
\hline Mean depth (m) & 0.23 & $0.08-0.56$ & -0.44 & -0.28 \\
\hline Mean velocity $\left(\mathrm{m} \cdot \mathrm{s}^{-1}\right)$ & 0.29 & $0.06-0.67$ & -0.61 & -0.06 \\
\hline Habitat cover $(\%)$ & 47 & $17-75$ & -0.44 & -0.23 \\
\hline Mean dominant substrate ${ }^{a}$ & 4.3 & $0.5-8.0$ & -0.50 & 0.36 \\
\hline Stream gradient $(\%)$ & 1.1 & $0.4-4.6$ & -0.07 & 0.42 \\
\hline Open canopy $(\%)$ & 17 & $0-63$ & -0.20 & 0.29 \\
\hline $\begin{array}{l}\text { Mean summer stream } \\
\text { temperature }\left({ }^{\circ} \mathrm{C}\right)\end{array}$ & 17.5 & $13.1-20.8$ & 0.54 & -0.32 \\
\hline $\mathrm{CV}$ of summer stream temperature & 0.13 & $0.06-0.25$ & -0.14 & 0.21 \\
\hline \multicolumn{5}{|l|}{ WATER QUALITY VARIABLES } \\
\hline Dissolved oxygen $\left(\mathrm{mg} \cdot \mathrm{L}^{-1}\right)$ & 8.7 & $7.3-10.9$ & -0.35 & 0.56 \\
\hline $\begin{array}{l}\text { Dissolved ammonia }+ \text { organic } \\
\quad \text { nitrogen }\left(\mathrm{mg} \cdot \mathrm{L}^{-1}\right)\end{array}$ & 0.17 & $0.08-0.38$ & 0.77 & -0.32 \\
\hline Total phosphorus $\left(\mathrm{mg} \cdot \mathrm{L}^{-1}\right)$ & 0.04 & $<0.01-0.13$ & 0.70 & -0.39 \\
\hline Chloride $\left(\mathrm{mg} \cdot \mathrm{L}^{-1}\right)$ & 42 & $7-150$ & 0.72 & -0.14 \\
\hline Number of pesticides & 7 & $0-14$ & -0.03 & 0.42 \\
\hline \multicolumn{5}{|l|}{ URBAN VARIABLES } \\
\hline Developed land (\%) & 40 & $0-87$ & 0.78 & 0.31 \\
\hline Forested land $(\%)$ & 12 & $1-68$ & -0.63 & -0.56 \\
\hline Homes on sewer $(\%)$ & 94 & $1-100$ & 0.81 & 0.14 \\
\hline Road density $\left(\mathrm{km} \cdot \mathrm{km}^{-2}\right)$ & 12.5 & $0-27.8$ & 0.34 & 0.29 \\
\hline Socioeconomic index $1^{\mathrm{b}}$ & 6.2 & $0-10$ & 0.36 & 0.13 \\
\hline Socioeconomic index $2^{\mathrm{b}}$ & 6.3 & $0-10$ & 0.75 & 0.46 \\
\hline Urban index & 68 & $0-100$ & 0.78 & 0.36 \\
\hline
\end{tabular}

aThe dominant substrate was characterized as follows: 0.1, silt or smooth bedrock; 0.5 , sand ( $>0.063-2 \mathrm{~mm})$; , fine/medium gravel ( $>2-16 \mathrm{~mm}) ; 2$, coarse gravel (>16-32 mm); 3, very coarse gravel (>32-64 mm); 4, small cobble (>64-128 mm); 6, large cobble (>128-256 mm); 8, small boulder $(>256-512 \mathrm{~mm}) ; 10$, large boulder, irregular bedrock, irregular hardpan, or irregular artificial surface.

${ }^{\mathrm{b}}$ Socioeconomic index 1 increases with average household income, household expenditure levels, and number of bedrooms. Socioeconomic index 2 increases with the density of housing units, number of households, percentage of rental units, and population.

bedrooms. The 2 nd socioeconomic index (SEI 2) was used in the calculation of the urban index and increased with the density of housing units, number of households, percentage of rental units, and population. These individual urban measures were selected in addition to the urban index to examine which type of measure showed the best relation to fish community structure.

\section{Statistical Analyses}

Fish communities were examined using nonmetric multidimensional scaling (NMDS). NMDS was first introduced in the 1960s in the fields of psychology and sociology (Kruskal 1964) and has gained popularity in ecology with the advent of computers capable of the necessary iterative calculations (Barger and Esch 2001, Roy et al. 2003, Picking and Veneman 2004, Thomson et al. 2005). NMDS is an ordination technique that reduces dimensionality while accurately maintaining among-sample distances. NMDS is similar in concept to other ordination techniques such as principal components analysis or correspondence analysis; however, it has several advantages. NMDS does not assume linear relationships among variables, uses ranked distances, and allows the use of any distance measure (McCune and Grace 2002). The technique calculates the similarity of each sample to all other samples, ranks the sites relative to each other (e.g., site 1 is more similar to site 2 than it is to site 3 ), and produces a 2- or 3-dimensional ordination of these ranks, such that sites that are most similar are plotted close together, while sites with the least similarity are plotted further apart. The "fit" of the ordination is assessed by the stress value. Conceptually, stress compares the original distances between samples calculated from the full data matrix with the distances calculated between samples in the lower dimension 
ordination space. Stress of $<0.20$ indicates a useful ordination (Clarke and Warwick 2001). For a detailed description of the technique, see Schiffmann et al. (1981) or Field et al. (1982). Fish abundance data were standardized prior to analysis as catch per unit effort (CPUE), based on the number of individuals captured per minute of electrofishing effort. The Bray-Curtis similarity coefficient was used for the fish NMDS ordination. We used the program Primer-e (version 6 beta R10) to calculate the NMDS (Clarke and Warwick 2001).

Patterns of physical habitat, water quality, and urban variables at the sampling sites and their relations to fish communities were also explored using an NMDS ordination. Environmental data were standardized $(\bar{x}=0, s=1)$ prior to analysis and a Euclidian distance measure was used in the ordination. Site scores for axis 1 of the environmental NMDS were correlated (Spearman's correlation) with the original environmental variables to determine which variables were responsible for site distribution along the axis. Site group designations determined from the fish NMDS ordination were used in the environmental NMDS plot to visually examine the potential associations of environmental conditions with fish communities. $T$ tests were used to evaluate statistical differences of individual environmental characteristics between fish community site groups.

\section{RESUlTS}

Urban intensity, measured by the urban index, was highest (100) at the downstream Mill Creek site (M300) and lowest (0) at the upstream Big Cottonwood Creek site (BCWTP; Table 1). Only BCWTP and the upstream Mill Creek site (M3060) were unaffected by water infrastructure. Types of water infrastructure varied independently of urban intensity and drainage area (Table 1). Sites represented a wide range of physical, water-quality, and urban conditions (Table 2). Despite the wide range in values observed for a number of environmental variables, few seem intrinsically stressful to fish. Some possible exceptions occurred at 3 study sites (HOLM, LCMU, LCWH) where mean summer water temperature exceeded $20^{\circ} \mathrm{C}$, and at 6 sites (BCMAL, HOLM, KAYL, LCCRE, LCWH, P800) where the number of pesticides detected exceeded 10.
Twenty-three fish species were captured (Table 3). Thirteen of the 28 sites had only 1 or 2 species, and the maximum species richness per site was 10 (Table 1). Nonnative Salmo trutta (brown trout) and native Catostomus platyrhynchus (mountain sucker) were the most frequently collected species, each captured at 16 of the 28 sites (Table 3).

Brown trout were abundant at 14 of 16 sites where they occurred, both in terms of percent relative abundance $(32 \%-100 \%$; Fig. 2$)$ and number of individuals (42-251). At HCEN only 6 brown trout were captured, but they comprised $40 \%$ of the total catch. At LCWH 1 brown trout was captured, which comprised $<1 \%$ of the relative abundance of fish fauna at this site. Young-of-the-year brown trout were collected at 13 of the sites, indicating the presence of self-reproducing populations (not captured at HCEN, LCWH, or BCMAL). Mountain sucker were of moderate to high abundance at 10 of 16 sites where they occurred $(>20 \%$ relative abundance and $>10$ individuals). At 5 of the remaining 6 sites where mountain sucker occurred (OHAR, OVAL, OWAS, P800, M300), mountain sucker were found in low abundance and brown trout or sculpins were the most abundant species. At the remaining site (SFK) a single mountain sucker was the only fish collected.

Ordination of fish abundance data identified 2 large groups of sites with distinctive fish communities, some intermediate sites, and 4 sites with very different communities (Fig. 3). Examination of species data (Fig. 2) indicates that sites plotting near the center left of the ordination plot in figure 3 have fish communities with brown trout and Cottus spp. (Paiute sculpin and mottled sculpin). Sites plotting to the right of the ordination plot are those dominated by mountain sucker. Three sites (BCMAL, BC900, M300) plot intermediate to these 2 groups, and they have populations of both brown trout and mountain sucker. The mountain sucker group may be further divided into those sites with populations of Rhinichthys osculus (speckled dace; HOLM, LCWH, LCMU, LCCRE) and those without (FARM, K1000, NKHO, BAFR, SFK). Fish communities at the outlying sites (KAYL, PARL, E1300, EWMIN) were each dominated by a single different taxon (Lepomis cyanellus, green sunfish; Oncorhynchus clarkii, cutthroat trout; Oncorhynchus mykiss, rainbow trout; and $O$. 
TABLE 3. Scientific and common names of native and nonnative fish species collected, and number of sites where each species was captured.

\begin{tabular}{llrl}
\hline Scientific name & Common name & Native & Number of sites \\
\hline Ameiurus melas & black bullhead & No & 1 \\
Carassius auratus & goldfish & No & 1 \\
Catostomus ardens & Utah sucker & Yes & 4 \\
Catostomus platyrhynchus & mountain sucker & Yes & 16 \\
Cottus bairdi & mottled sculpin & Yes & 9 \\
Cottus beldingii & Paiute sculpin & Yes & 1 \\
Cyprinidae & minnow spp. & - & 2 \\
Cyprinus carpio & common carp & No & 4 \\
Gambusia sp. & mosquitofish & No & 1 \\
Ictalurus punctatus & channel catfish & No & 1 \\
Lepomis cyanellus & green sunfish & No & 5 \\
Lepomis macrochirus & bluegill & No & 3 \\
Lepomis microlophus & redear sunfish & No & 1 \\
Micropterus salmoides & largemouth bass & No & 2 \\
Morone chrysops & white bass & No & 1 \\
Oncorhynchus clarkii & cutthroat trout & Yes & 2 \\
Oncorhynchus mykiss & rainbow trout & No & 10 \\
Pimephales promelas & fathead minnow & No & 3 \\
Prosopium williamsoni & mountain whitefish & Yes & 6 \\
Rhinichthys osculus & speckled dace & Yes & 7 \\
Salmo trutta & redside shiner & Yes & 1 \\
Sander vitreus & brown trout & No & No \\
\hline
\end{tabular}

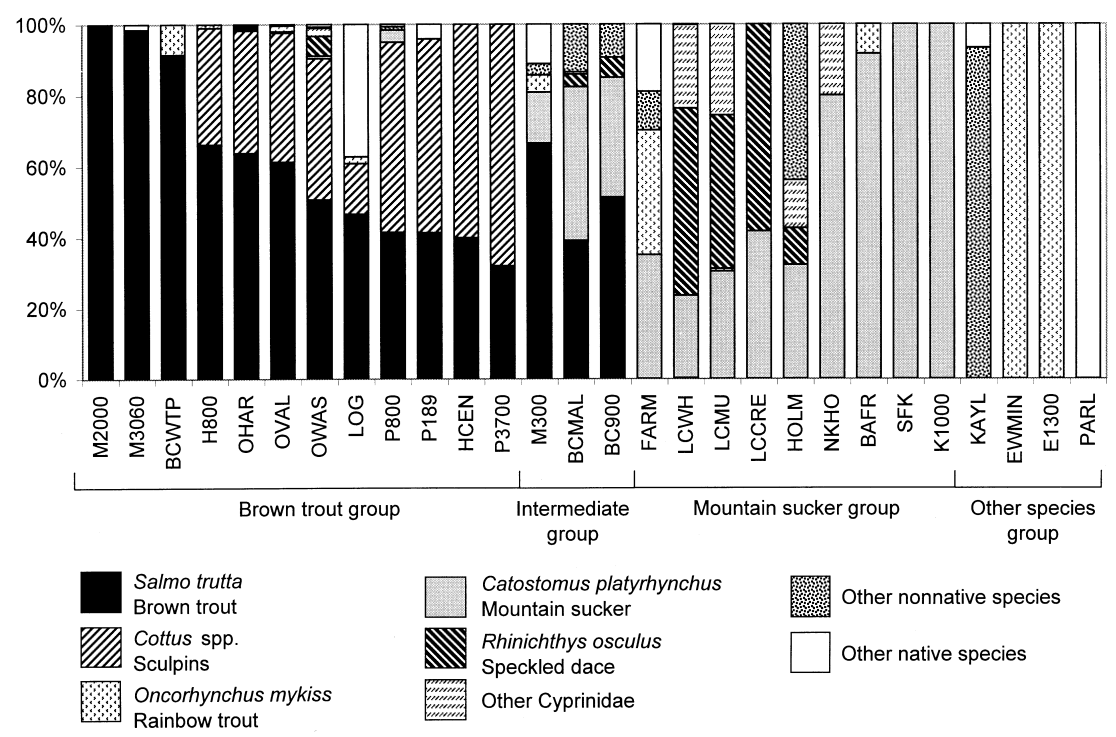

Fig. 2. Relative abundance of fish species or groups. Sites indicated by brackets are groups identified from fish NMDS plot.

mykiss, respectively) with no occurrence of either brown trout or mountain sucker.

Based on the environmental NMDS plot, sites with brown trout communities appear to have different environmental characteristics than other sites studied (Fig. 4). Sites with mountain sucker communities, sites with intermediate communities, and "outlying" sites with unique communities are not clearly different in environmental conditions, indicating that 


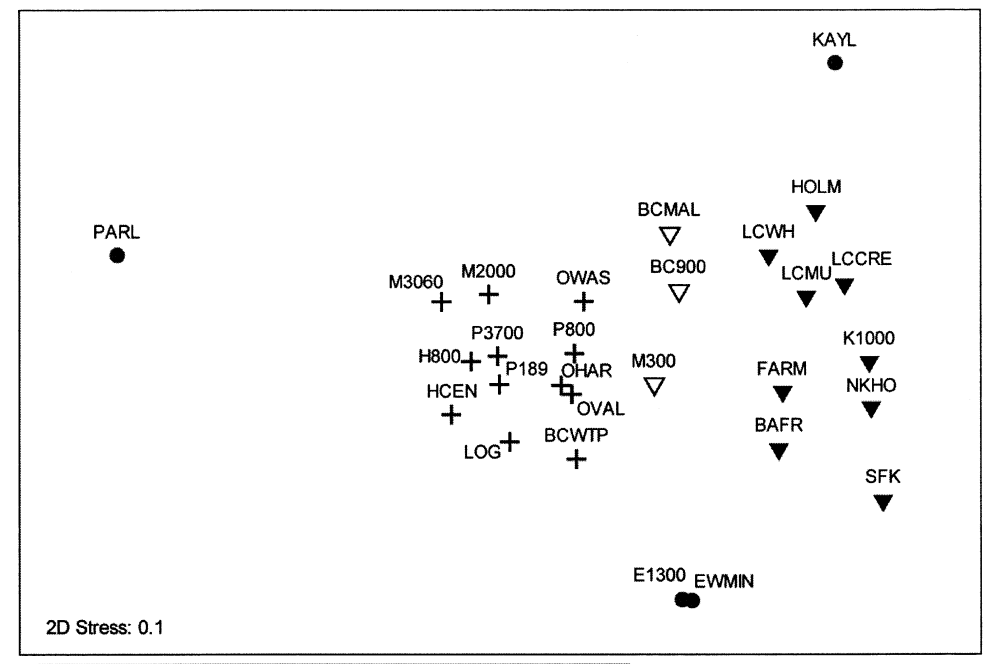

Fish Community Groups

+ Brown trout

$\boldsymbol{\nabla}$ Mountain sucker

$\nabla$ Intermediate (brown trout and mountain sucker)

- Other species

Fig. 3. Two-dimensional ordination diagram of sites from nonmetric multidimensional scaling $(n=28)$ of fish catch per unit effort (fish $\cdot$ min $\left.^{-1}\right)$. Four site groups were identified based on species composition.

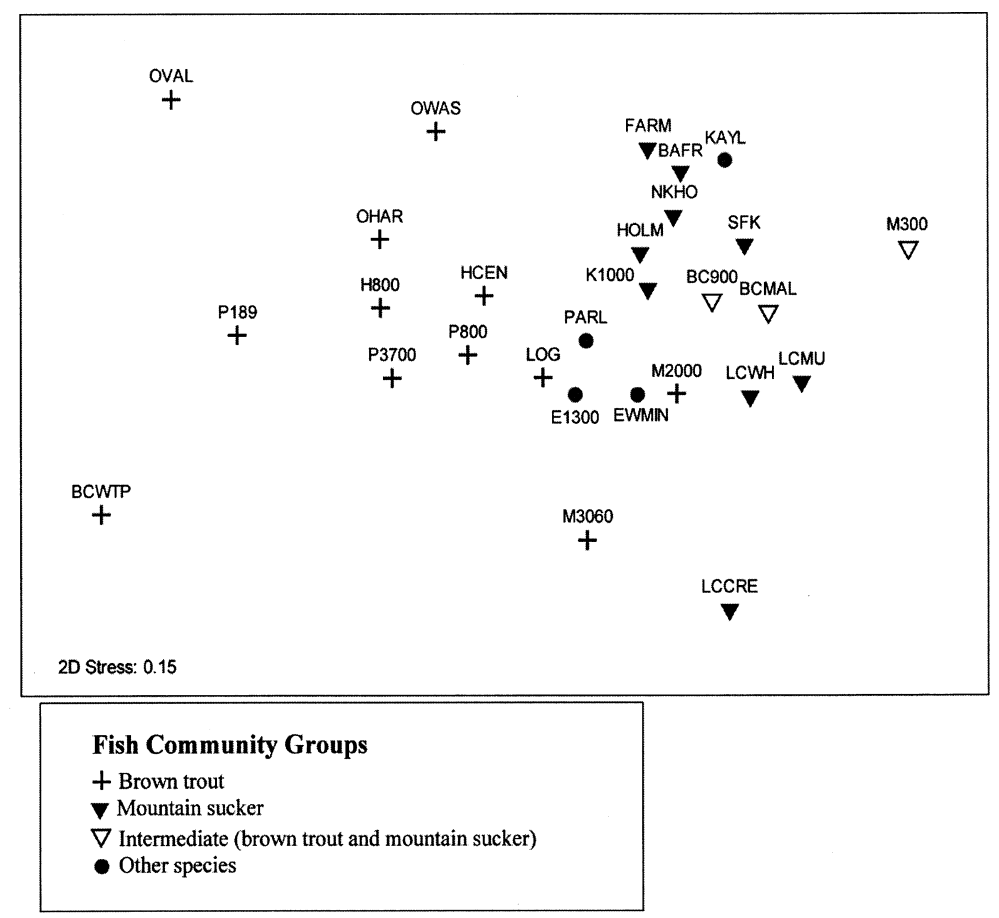

Fig. 4. Two-dimensional ordination diagram of sites from nonmetric multidimensional scaling $(n=28)$ of environmental and urban variables. Environmental data were standardized and centered prior to analysis. Fish community groups identified in Fig. 3 are indicated using distinct symbols. 
TABLE 4. Means and ranges of urban and environmental variables for sites in fish community groups: brown trout sites (group A, $n=12$ ) and mountain sucker sites (group B, $n=9$ ). Means were considered statistically different at $P<0.05$ (in bold). $P$-values $<0.10$ are shown.

\begin{tabular}{|c|c|c|c|c|c|}
\hline \multirow[b]{2}{*}{ Variable } & \multicolumn{2}{|c|}{ Group A (brown trout) } & \multicolumn{2}{|c|}{ Group B (mountain sucker) } & \multirow[b]{2}{*}{$P$-value } \\
\hline & $\bar{x}$ & range & $\bar{x}$ & range & \\
\hline \multicolumn{6}{|l|}{ PHYSICAL VARIABLES } \\
\hline Elevation $(\mathrm{m})$ & 1400 & $1310-1540$ & 1330 & $1250-1390$ & 0.007 \\
\hline Discharge $\left(\mathrm{m}^{3} \cdot \mathrm{s}^{-1}\right)$ & 1.20 & $0.01-3.57$ & 0.07 & $0.01-0.14$ & 0.003 \\
\hline Mean depth (m) & 0.34 & $0.13-0.55$ & 0.15 & $0.08-0.30$ & $<0.001$ \\
\hline Mean velocity $\left(\mathrm{m} \cdot \mathrm{s}^{-1}\right)$ & 0.44 & $0.07-0.67$ & 0.19 & $0.06-0.37$ & 0.002 \\
\hline Habitat cover $(\%)$ & 60 & $34-75$ & 38 & $17-53$ & 0.002 \\
\hline Mean dominant substrate & 5.7 & $3.6-8.0$ & 2.6 & $0.6-5.5$ & 0.001 \\
\hline Stream gradient $(\%)$ & 1.3 & $0.40-4.6$ & 1.2 & $0.62-1.9$ & \\
\hline Open canopy $(\%)$ & 24 & $1-63$ & 21 & $0-47$ & \\
\hline $\begin{array}{l}\text { Mean summer stream } \\
\text { temperature }\left({ }^{\circ} \mathrm{C}\right)\end{array}$ & 15.9 & $13.1-18.1$ & 18.7 & $15.4-20.8$ & 0.001 \\
\hline $\begin{array}{l}\mathrm{CV} \text { of summer stream } \\
\text { temperature }\end{array}$ & 0.13 & $0.06-0.16$ & 0.14 & $0.09-0.25$ & \\
\hline \multicolumn{6}{|l|}{ WATER QUALITY VARIABLES } \\
\hline Dissolved oxygen $\left(\mathrm{mg} \cdot \mathrm{L}^{-1}\right)$ & 9.4 & $8.2-10.9$ & 8.6 & $7.3-10.9$ & \\
\hline $\begin{array}{l}\text { Dissolved ammonia }+ \\
\quad \text { organic nitrogen }\left(\mathrm{mg} \cdot \mathrm{L}^{-1}\right)\end{array}$ & 0.10 & $0.08-0.19$ & 0.26 & $0.20-0.38$ & $<0.001$ \\
\hline Total phosphorus $\left(\mathrm{mg} \cdot \mathrm{L}^{-1}\right)$ & 0.027 & $<0.01-0.05$ & 0.08 & $0.02-0.11$ & 0.001 \\
\hline Chloride $\left(\mathrm{mg} \cdot \mathrm{L}^{-1}\right)$ & 22 & $6.6-59$ & 66 & $21-120$ & 0.006 \\
\hline Number of pesticides & 5 & $1-10$ & 5.8 & $0-12$ & \\
\hline \multicolumn{6}{|l|}{ URBAN VARIABLES } \\
\hline Developed land (\%) & 29 & $0-69$ & 49 & $24-80$ & 0.05 \\
\hline Forested land (\%) & 20 & $3-68$ & 12 & $3-30$ & \\
\hline Homes on sewer $(\%)$ & 60 & $1-98$ & 97 & $93-100$ & 0.002 \\
\hline Road density $\left(\mathrm{km} \cdot \mathrm{km}^{-2}\right)$ & 20.7 & $0-40$ & 18 & $12-27$ & \\
\hline Socio-economic index $1^{b}$ & 5.1 & $0-10$ & 8.1 & $5.4-10$ & 0.012 \\
\hline Socio-economic index $2^{b}$ & 4.7 & $0-10$ & 7.0 & $4.8-8.9$ & 0.044 \\
\hline Urban Index & 47 & 0-88 & 70 & $46-90$ & 0.022 \\
\hline
\end{tabular}

aThe dominant substrate was characterized as follows: 0.1 , silt or smooth bedrock; 0.5 , sand ( $>0.063 \mathrm{~mm}$ and $\leq 2 \mathrm{~mm}) ; 1$, fine/medium gravel ( $>2 \mathrm{~mm}$ and $\leq 16$ $\mathrm{mm}) ; 2$, coarse gravel ( $>16 \mathrm{~mm}$ and $\leq 32 \mathrm{~mm}) ; 3$, very coarse gravel $(>32 \mathrm{~mm}$ and $\leq 64 \mathrm{~mm}) ; 4$, small cobble $(>64 \mathrm{~mm}$ and $\leq 128 \mathrm{~mm}) ; 6$, large cobble $(>128-256$ $\mathrm{mm}) ; 8$, small boulder (>256-512 mm); 10, large boulder, irregular bedrock, irregular hardpan, or irregular artificial surface.

bSocioeconomic index 1 increases with average household income, household expenditure levels and number of bedrooms. Socioeconomic index 2 increases with the density of housing units, number of households, percentage of rental units, and population.

factors other than environmental conditions may be driving fish community composition at these sites. Site scores for axis 1 of the environmental NMDS were positively correlated with dissolved organic nitrogen, total phosphorus, chloride, percent developed land, percent houses on sewer, urban index, housing density (SEI 2), and mean summer temperature (Table 2). Negative correlations were observed for percent forested land, dominant substrate, elevation, discharge, and mean velocity.

Nine environmental variables, 4 urban variables, and elevation were significantly different between sites with brown trout communities and sites with mountain sucker communities (Table 4). Environmental variables for these groups remained significantly different regard- less of whether the 3 intermediate sites (both with brown trout and mountain sucker) were combined into either group. Sites with brown trout communities had higher discharge and velocity; more habitat cover; larger substrate; deeper average depth; lower stream temperatures; and lower concentrations of dissolved organic nitrogen, total phosphorus, and chloride than sites with mountain sucker communities. In addition, these sites tended to be less urban and at higher elevations. Sites with brown trout communities had a lower percentage of houses on sewer. Brown trout sites also had lower urban index scores, less dense housing (SEI 2), and higher household income (SEI 1); but significance values were somewhat higher than for comparisons based on other variables $(0.01<P<0.04)$. 


\section{DisCussion}

The 28 sites in the study represented a range of urban conditions characteristic of wadeable, perennially flowing streams in the Wasatch Front metropolitan area. Fish communities were distributed along a community gradient, ranging from sites with high CPUE of nonnative brown trout to sites with high CPUE of native mountain sucker. The community gradient was correlated with a variety of physical, water-quality, and urban variables. As flow volumes decreased, resulting in warmer water temperatures and declining velocities, communities shifted from dominance by brown trout to dominance by mountain sucker. However, sites with warmer temperatures and generally lower water-quality conditions were able to support brown trout if they had adequate depth and habitat cover. Mountain sucker and speckled dace were relatively abundant at sites in more urbanized areas and appeared to be tolerant of existing water-quality and habitat conditions.

Three sites that supported trout species other than brown trout (rainbow trout at EWMIN and E1300, and cutthroat trout at PARL) appeared to have environmental conditions somewhat intermediate between the brown trout sites and the mountain sucker sites. It is not clear why these sites supported such different communities. Fish abundance at these sites was low (5 fish at EWMIN and E1300, 10 fish at PARL), and all fish captured appeared to be adults. These observations suggest the possibility of prior human intervention, such as accidental or recreational introduction of fish into isolated stream reaches. The site supporting primarily green sunfish (KAYL) was our most lentic-like stream reach. Several months prior to sampling at this site, an upstream landslide temporarily blocked flow in the channel and moved considerable sediment into the stream. The resulting channel conditions may have favored occurrence of green sunfish, which are well adapted to stressful environmental conditions such as those found in the pools of intermittent streams.

Study sites were located in watersheds with varying levels of urban intensity, and urbanization has been shown to alter physical and waterquality conditions of streams (reviewed by Paul and Meyer 2001). The physical-chemical gradient identified by NMDS axis 1 was significantly correlated with the urban index and most of the individual measures of urbanization. This gradient also correlated with elevation, which was not unexpected as urbanization is generally less intense at higher elevations because of topographic constraints on development. In the site selection process we tried to minimize elevation as a factor; however, we had only limited success due to the strong elevational gradient in the area. The association of elevation and urban development is typical of mountain front urban areas in the western United States. However, 6 of the 15 sampled sites below $1350 \mathrm{~m}$ supported populations of brown trout (9 supported mountain sucker and 3 supported other species), indicating that elevation is not the sole reason for the distribution of fish communities.

Sites in more urbanized areas typically had higher dissolved constituent concentrations and lower discharge. Smaller streams in this study may be more susceptible to changes in water quality caused by urbanization because they have lower dilution capacity. Additionally, although lower discharge is generally the result of smaller drainage area, urbanization has been shown to reduce baseflow (USEPA 1997, Finkenbine et al. 2000), which may further limit streams with marginal habitat availability to support some fish species. The primary individual urban metrics that appear to be driving the relation between urbanization, stream size, and water quality imply that an increase in developed land, percentage of houses on sewer, and housing density (SEI 2) contribute to the changes in the physical and chemical environment. We did not see a relation between road density or household income (and presumably household size; SEI 1) and stream quality. The conversion of forested land to developed land in a watershed has been shown to decrease water quality and alter physical habitat of streams (Lenat and Crawford 1994). The mechanism accounting for the importance of percentage of houses on sewer is unknown. Potentially this variable may be a surrogate for housing density or housing age. Subdivisions using septic systems tend to be located in areas of lower density, where sewers are not economically viable, or in new housing developments that fall outside of metropolitan boundaries; thus, they may not be as heavily regulated. The use of several measures of urbanization, rather than land-use alone, may shed light on particular aspects of the developed landscape that have 
the greatest impact on streams. Our results suggest that housing density is a key landscape feature for the Wasatch Front; further research is needed.

Although we did not assess the effects of water infrastructure quantitatively, the movement of water across and within watersheds and the alteration of hydrologic regimes can markedly affect the chemical, physical, and biological environment of streams. In the case of fish communities, this infrastructure may play a key role in dispersal of nonnative species. Other than brown trout, most nonnative fish collected were warm-water lentic species (green sunfish; Lepomis macrochirus, bluegill; L. microlophus, redear sunfish; Cyprinus carpio, common carp; Sander vitreus, walleye; Ameiurus melas, black bullhead; Ictalurus punctatus, channel catfish; Micropterus salmoides, largemouth bass; Morone chrysops, white bass). Warm-water lentic species are stocked in local lakes and reservoirs and can move through low-velocity canals that connect streams along the Wasatch Front. The 2 sites with the highest diversity of nonnative species were $<4 \mathrm{~km}$ downstream from a canal water exchange point (BCMAL, BC900). Surprisingly, other than brown trout, nonnative fish species were generally not abundant at the study sites. This finding is contrary to some other studies of disturbed streams in the western United States (e.g., Meefe et al. 1983, Gido and Propst 1999, Brown 2000, Brown and Ford 2002, Schultz et al. 2003) where nonnative species are well established. The absence of warm, low-velocity habitat appears to be the factor limiting populations of most nonnative species along the Wasatch Front. Larger, nonwadeable, low-gradient, low-elevation streams in the study area support populations of nonnative species such as common carp, white bass, and green sunfish (Holden and Crist 1987). Only 2 of the sampled sites had slopes $<0.5 \%$, and nearly all contained riffles; these conditions are favored by both mountain sucker and speckled dace (Sigler and Sigler 1996), the dominant native species. Other than brown trout, the only nonnative species captured in abundance was Pimephales promelas (fathead minnow), which appears to be established in Little Cottonwood Creek (2 of the 3 Little Cottonwood Creek sites). Fathead minnow is a generalist and tolerant of relatively harsh environments such as streams with highly fluctuating flows (Moyle 2002). Given the success of fathead minnow in colonizing these sites, it is likely that the distribution of other generalist species may increase, especially at sites where habitat is limited for established native species.

The brown trout was the most widely distributed and abundant species in Wasatch Front urban streams. The success of brown trout is not surprising considering the effort to establish introduced trout populations. Brown trout were first introduced as a sport fish in about 1895 (Holden et al. 1997), and stocking of brown trout and rainbow trout continued into the late 20th century. However, with the exception of the Logan River, the study streams have not been stocked with brown trout in the previous 10 years (T. Miles, Utah Division of Wildlife Resources, personal communication), supporting our conclusion that most brown trout populations we sampled are self-sustaining.

Once established, the continued success of brown trout in urban streams may be related to their life history. Brown trout in Utah are rarely abundant in the smaller, colder, highelevation reaches of mountain streams and are generally more abundant than other trout species in larger, warmer streams (Sigler and Sigler 1996). Brown trout have an optimum temperature range of $18^{\circ}-24^{\circ} \mathrm{C}$ (Jenkins and Burkhead 1993) and tolerate relatively warmer water temperatures better than other trout species. Brown trout can also tolerate relatively high turbidities for brief periods (Sigler and Sigler 1996). The presence of upstream impoundments might also contribute to the success of brown trout in these urban streams. Upstream impoundments moderate natural fall flood flows, thereby reducing scour of the fall-spawning brown trout nests. The earlier spawning time of brown trout results in surviving young-of-the-year having a size advantage over spring-spawning species, such as the native trout and suckers. In the short term, this gives brown trout a competitive advantage over spring-spawning trout, such as cutthroat trout, and in the long term may lead to suppression of native species by larger piscivorous brown trout (Moyle and Vondracek 1985, Strange et al. 1992). Reproductive advantages of brown trout combined with the rarity of native cutthroat trout in these urban waters and the relatively lower tolerance of cutthroat trout for the environmental conditions present in urban systems make it unlikely that cutthroat trout will become established in the area without a major management effort. 
Stream size and water quality appear to be the most important factors driving fish community distribution in Wasatch Front urban streams. Larger streams had similar fish communities dominated by brown trout. Water quality declined as urban intensity increased, especially as the amount of developed land and the percentage of houses on sewer increased. As urbanization of the Wasatch Front continues, maintaining healthy stream ecosystems will likely become an important quality-of-life issue for the urban population. Continued research into the relations of stream biota with the environmental changes resulting from urbanization will be critical for the proper management of these streams.

\section{ACKNOWLEDGMENTS}

We thank Thomas F. Cuffney and Gerard McMahon of the U.S. Geological Survey, North Carolina Water Science Center, for guidance in project design and GIS support. Numerous staff from the U.S. Geological Survey, Utah Water Science Center, provided logistical support and collected field data, namely, S. Gerner, J. Cederberg, and C. Albano. R. Baskin assisted with interpretation of water-quality data. Funding was provided by the U.S. Geological Survey National Water-Quality Assessment Program, Great Salt Lake Basins Study Unit. The use of firm, trade, or brand names in this article is for identification purposes only and does not constitute endorsement by the U.S. Geological Survey.

\section{Literature Cited}

Batr, K.E., AND C.M. Pringle. 2000. Special problems of urban river conservation: the encroaching megalopolis. Pages 385-402 in P.J. Boon, B.R. Davies, and G.E. Petts, editors, Global perspectives on river conservation: science policy, and practice. John Wiley, New York.

Barger, M.A., AND G.W. Esch. 2001. Downstream changes in the composition of the parasite community of fishes in an Appalachian stream. Journal of Parasitology 87:250-255.

BoоTH, D.B., AND C.R. JaCKson. 1997. Urbanization of aquatic systems: degradation thresholds, stormwater detection, and the limits of mitigation. Journal of the American Water Resources Association 33:1077-1090.

Brown, L.R. 2000. Fish communities and their associations with environmental variables, lower San Joaquin River drainage, California. Environmental Biology of Fishes 57:251-269.

Brown, L.R., AND T.J. Ford. 2002. Effects of flow on the fish communities of a regulated California river: im- plications for managing native fishes. River Research and Applications 18:331-342.

Campbell, P. 1997. Population projections: states 19952025. Current population report P25-1131, U.S. Census Bureau.

Clarke, K.R., AND R.M. WarWick. 2001. Change in marine communities: an approach to statistical analysis and interpretation. 2nd edition. PRIMER-E Ltd., Plymouth, U.K.

Douglas, I. 1983. The urban environment. Edward Arnold, London.

Field, J.G., K.R. Clakke, and R.M. Warwick. 1982. A practical strategy for analyzing multispecies distribution patterns. Marine Ecology-Progress Series $8: 37-52$.

Finkenbine, J.K., J.W. Atwater, and D.S. Mavinic. 2000. Stream health after urbanization. Journal of the American Water Resources Association 36:1149-1160.

Fishman, M.J., J.W. Raese, C.N. Gerlitz, and R.A. HusBAND. 1994. U.S. Geological Survey approved inorganic and organic methods for the analysis of water and fluvial sediment, 1954-94. Open-File Report 94351, U.S. Geological Survey, Denver, CO.

Fitzpatrick, F.A., I.R. Waite, P.J. D'Arconte, M.R. Meador, M.A. Maupin, and M.E. Gurtz. 1998. Revised methods for characterizing stream habitat in the national water-quality assessment program. WaterResources Investigations Report 98-4052, U.S. Geological Survey, Raleigh, NC.

Gido, K.B., and D.L. Propst. 1999. Habitat use and association of native and nonnative fishes in the San Juan River, New Mexico and Utah. Copeia 1999:321-332.

Hammer, T.R. 1972. Stream channel enlargement due to urbanization. Water Resources Research 8:1530-1540.

Holden, P.B., AND L.B. CRIst. 1987. Fishery and macroinvertebrate studies of the Jordan river in Salt Lake County, November 1986. Prepared by BIO/WEST, Inc. for the Central Valley water reclamation facility board, Salt Lake City; Logan, UT.

Holden, P.B., S.J. Zucker, P.D. Abate, and R.A. Valdez. 1997. Assessment of the effects of fish stocking in the state of Utah: past, present and future. Prepared by BIO/WEST, Inc. for the Utah Division of Wildlife Resources, Logan, UT.

Jenkins, R.E., And N.M. Burkhead. 1993. Freshwater fishes of Virginia. American Fisheries Society, Bethesda, MD.

Kemp, S.J., AND J.R. SpotiLa. 1997. Effects of urbanization on brown trout Salmo trutta, other fishes and macroinvertebrates in Valley Creek, Valley Forge, Pennsylvania. American Midland Naturalist 138: 55-68.

KLEIN, R.D. 1979. Urbanization and stream quality impairment. Water Resources Bulletin 15:948-963.

KruSKaL, J.B. 1964. Multidimensional scaling by optimizing goodness of fit to a nonmetric hypothesis. Psychometrika 29:1-27.

Lenat, D.R., and J.K. Crawford. 1994. Effects of land use on water quality and aquatic biota of three North Carolina Piedmont streams. Hydrobiologia 294:185199.

Loveland, T.R., AND D.M. SHaw. 1996. Multi-resolution land characterization: building collaborative partnerships. Pages 83-90 in J.M. Scott, T. Tear, and F. Davis, editors, GAP analysis: a landscape approach to biodiversity planning. Proceedings of the ASPRS/GAP Symposium, Charlotte, NC. National Biological Service, Moscow, ID. 
McCune, B., AND J.B. Grace. 2002. PC-ORD. Analysis of ecological communities. MjM Software Design, Gleneden Brach, OR.

MCMAHON, G., AND T.F. CuFFnEy. 2000. Quantifying urban intensity in drainage basins for assessing stream ecological conditions. Journal of the American Water Resources Association 36:1247-1261.

Meefe, G.K., D.A. Hedrickson, W.L. Minckley, and J.N. RINNE. 1983. Factors resulting in decline of the endangered Sonoran topminnow Poeciliopsis occidentalis (Atheriniformes: Poeciliidae) in the United States. Biological Conservation 25:135-159.

Moyle, P.B. 2002. Inland fishes of California. 2nd edition. University of California Press, Berkeley.

Moyle, P.B., AND B. VondraceK. 1985. Structure and persistence of the fish assemblage in a small Sierra stream. Ecology 66:1-13.

OMERNiK, J.M. 1994. Ecoregions: a spatial framework for environmental management. Pages 49-62 in W.S. Davis and T.P. Simon, editors, Biological assessment and criteria: tools for water resource planning and decision making. Lewis Publishers, Boca Raton, FL.

Patton, T.M., W.A. Hubert, F.J. Rahel, and K.G. Gerow. 2000. Effort needed to estimate species richness in small streams on the Great Plains in Wyoming. North American Journal of Fisheries Management 20:394398.

Paul, M.J., AND J.L. MeYer. 2001. Streams in the urban landscape. Annual Review of Ecology and Systematics 32:333-365.

Pedersen, E.R., and M.A. Perkins. 1986. The use of benthic invertebrate data for evaluating the effects of urban runoff. Hydrobiologia 139:13-22.

Picking, D.J., AND P.L.M. Veneman. 2004. Vegetation patterns in a calcareous sloping fen of southwestern Massachusetts, USA. Wetlands 24:514-528.

Platts W.S., C. Armour, G.D. Booth, M. Bryant, J.L. BufFORD, P. Culpin, S. Jensen, ET AL. 1987. Methods for evaluating riparian habitats with applications to management. General Technical Report INT-221, USDA Forest Service.

Roy, A.H., A.D. Rosemond, M.J. Paul, D.S. Leigh, and J.B. WALLACE. 2003. Stream macroinvertebrate response to catchment urbanization (Georgia, USA). Freshwater Biology 48:329-346.

SChiffmann, S.S., M.L. Reynolds, and F.W. Young. 1981. Introduction to multi-dimensional scaling: theory, methods and applications. Academic Press, London.

Schultz, A.A., O.E. Maughan, and S.A. Bonar. 2003. Effects of flooding on abundance of native and nonnative fishes downstream from a small impoundment. North American Journal of Fisheries Management 23:503-511.

ScotT, J.B., C.R. STEWARD, AND Q.J. STOBER. 1986. Effects of urban development on fish population dynamics in
Kelsey Creek, Washington. Transactions of the American Fisheries Society 115:555-567.

Shelton, L.R. 1994. Field guide for collecting and processing stream-water samples for the national waterquality assessment program. Open-File Report 94455, U.S. Geological Survey, Sacramento, CA.

SigLER, W.F., AND J.W. SigLer. 1996. Fishes of Utah, a natural history. University of Utah Press, Salt Lake City.

Solley, W.B., R.R. Pierce, and H.A. Perlman. 1998. Estimated use of water in the United States in 1995. Circular 1200, U.S. Geological Survey.

Sonneman, J.A., C.J. Walsh, P.F. BreEn, and A.K. Sharpe. 2001. Effects of urbanization on streams of the Melbourne region, Victoria, Australia. II. Benthic diatom communities. Freshwater Biology 46:553-565.

Strange, E.M., P.B. Moyle, AND T.C. Foin. 1992. Interactions between stochastic and deterministic processes in stream fish community assembly. Environmental Biology of Fishes 36:1-15.

Thomson, J.R., D.D. HaRT, D.F. Charles, T.L. NightenGALE, AND D.M. WINTER. 2005. Effects of removal of a small dam on downstream macroinvertebrate and algal assemblages in a Pennsylvania stream. Journal of the North American Benthological Society 24: 192-207.

U.S. Census Bureau. 2000. Population household and economic topics. Accessed August 2005. Available from: www.census.gov/population/www/index.html

USEPA (U.S. Environmental Protection Agency). 1997. Urbanization and streams: studies of hydrologic impacts. EPA841-R-97-009. Washington, DC.

U.S. GEOLOGICAL Survey. 1995. Aggregated water-use data system (AWUDS). U.S. Geological Survey AWUDS database.

2000. National elevation dataset. U.S. Geological Survey. Accessed March 2000. Available from: gisdata.usgs.gov/ned/.

Walsh, C.J., A.K. Sharpe, P.F. Breen, and J.A. Sonneman. 2001. Effects of urbanization on streams of the Melbourne region, Victoria, Australia. I. Benthic macroinvertebrate communities. Freshwater Biology 46:535551.

Wang, L., J. Lyons, P. Kanehl, R. Bannerman, and E. EMMONS. 2000. Watershed urbanization and changes in fish communities in southeastern Wisconsin streams. Journal of the American Water Resources Association 36:1173-1189.

Weaver, L.A., AND G.C. GaRman. 1994. Urbanization of a watershed and historical changes in a stream fish assemblage. Transactions of the American Fisheries Society 123:162-172.

Received 17 August 2004 Accepted 10 October 2005 